\title{
ADOPTION OF MOBILE APPLICATIONS FOR IDENTIFYING TOURISM DESTINATIONS BY TRAVELLERS: AN INTEGRATIVE APPROACH
}

\author{
Tung-Sheng KUO ${ }^{1}$, Kuo-Chung HUANG ${ }^{2}$, Thang Quyet NGUYEN ${ }^{3}$, \\ Phuc Hung NGUYEN ${ }^{4}$ \\ 1, 2, ${ }^{4}$ Department of Business Administration, Nanhua University, Taiwan \\ ${ }^{3}$ Faculty of Tourism \& Hospitality Management, Ho Chi Minh City \\ University of Technology (HUTECH), 700000, Vietnam
}

Received 08 November 2018; accepted 14 May 2019

\begin{abstract}
The purpose of the study is to provide an assessment of both how consumers adopt mobile tourism apps and how consumers use those apps to orient customer intentions to visit tourism destinations. The technology acceptance model (TAM) is used to explore customer intentions to adopt tourism apps. A survey of 630 tourism respondents found that the e-servicescape environment and e-word-of-mouth communication play major roles in determining intentions to adopt tourism apps and to visit tourism destinations. Perceived ease of use and perceived usefulness tend to be moderators of the effects of the e-servicescape environment and e-word-of-mouth communication on attitudes towards using apps. The results may be important references to conduct further validations, and critical for marketing managers when designing specific criteria to enhance mobile apps and their adoption. The different managerial implications - including apps to differential marketing tools, improving attitudes towards using tourism apps, and segmenting customers in order to design marketing strategies - are considered.
\end{abstract}

Keywords: mobile tourism app, Technology Acceptance Model (TAM), e-Servicescape environment, e-Word-of-Mouth communication, perceived ease of use, perceived usefulness, mobile apps.

JEL Classification: M1, M3.

\section{Introduction}

In today's manufacturing business, almost all marketing activities use the results of modern technology to replace ineffective traditional marketing activities. Mobile apps provide an effective way for travel-related companies to build loyal relationships with customers. In today's business environment, mobile apps help travel-related companies provide exciting, interesting, and innovative experiences for their customers (Ukpabi \& Karjaluoto, 2017).

*Corresponding author. E-mail: hungnguyenphuc22@yahoo.com 
In the travel industry, mobile marketing devices help consumers identify and understand more about travel information, products, and services; and travel managers often use mobile devices to build marketing strategies for providers. Mobile apps bring huge benefits to consumers - but in fact, there have been very few researches on what factors may affect the use of consumer mobile apps; although mobile apps attract a lot of interests among a lot of people ( $\mathrm{Lu}, \mathrm{Mao}$, Wang, \& Hu, 2015). Besides, few studies have evaluated the impact of the relationship between other constructs (e-Servicescape environment, e-Word-of-mouth Communication) on tourists' attitudes towards using tourism apps. In particular, the interrelationship between eWOM communication or the e-servicescape environment and tourists' attitudes with the moderating effect of perceived usefulness and perceived ease of use is still unexplored. This interrelationship is the gap in the tourism industry that we will fulfill with this study by exploring the factors that affect mobile apps users in choosing travel destinations using the technology acceptance model (TAM).

To perform better research on consumer engagement with regards to the use of mobile apps, the problem is how to understand the difference between behavior and adoption. Along with the development of IT (Information Technology), tourists these days often use mobile apps in order to select tourism destinations as the most effective way. So what factors are affecting users' attitude towards using mobile apps and intention to visit tourism destinations? How do e-servicescape environment, eWOM communication, perceived ease of use and perceived usefulness affect users' attitude toward using tourism apps? How do these factors influence users' intention to adopt the apps and to visit tourism destinations?

To answer these questions, this study was first performed to explore the impact of tourism on the selection of destinations using a mobile app. This study was secondly conducted to determine the effect of the online environment through mobile apps for travelers. Thirdly, this article reviews the theoretical and empirical research on tourism destinations and considers the interaction effects of the e-servicescape environment and eWOM communication, based on the relationship between perceived ease of use and perceived usefulness. Fourthly, this study also considers the interaction effects of either intention to adopt tourism apps or intentions to visit tourism destinations.

This study will be organized as the following. Section 1 presents the research theories and hypotheses about the background of mobile marketing apps, Technology Acceptance Model (TAM) and our proposed research model. Section 2 presents the methodology while the finding in this study is presented in section 3. Section 4 demonstrates the discussion and conclusions which are critical for our implications, limitations and future study direction are developed in the last section.

\section{Research theories and hypotheses}

\subsection{The background of mobile marketing apps and Technology Acceptance Model (TAM)}

In today's marketing environment, mobile marketing is (seen as being) a positive solution in the digital age. According to an online survey, the number of global smartphone users has neared 17.5 billion on the global (eMarketer, 2014) and the smartphone penetration level had 
been expected to be close to 50\% of the potential global market in 2017 (eMarketer, 2016). Smartphone apps are integrated with the navigation system to perform location positioning function on personal phones to locate places and orient oneself more easily. Apps are used for a variety of purposes (such as catering, entertainment, travel, etc.).

Understanding the attitudes regarding the user adoption of mobile tourism apps, especially in a developing country like Vietnam, will aid in suggesting new ways to attract customers, new ways to develop tourism marketing strategies, and new ways to improve customer experience. When it comes to mobile marketing, it is important to differentiate between the two different types of mobile marketing apps. These are:

1. The level of understanding of the consumer, and

2. The trigger of communication.

In this study, by using the technology acceptance model (TAM), marketing strategies are evaluated through attitudes and intentions regarding using mobile apps. In addition, the impact of the factors affecting the attitudes and intentions of using mobile apps for marketing purposes will be assessed. The technology acceptance model (TAM) was created by Davis (1985), and then adopted by the theory of reasoned action. Its impact on the use of personal technology has been considered as involving elements of intent to use the technology, and as being a direct determinant of behaviour. Venkatesh, Davis, and Morris (2007) states that TAM, which is an information systems theory, is the most basic model to interpret Information Technology usage. It was described how new technology is accepted and be used.

Moreover, attitude reflects an individual's feeling while using technology and the technology acceptance model (TAM) determines attitudes by using two beliefs: perceived ease of use, and perceived usefulness. The app system is relatively easy to use - consumers easily learn how to use it and they ultimately intend to use it. Previous studies have shown that perceived ease of use has a positive effect on continued use in the current technology context (Chiu \& Wang, 2008). In addition, consumers are more likely to improve their performance - and this is especially important in the use of technological innovations, particularly in the use of mobile apps (Zhang, Abound Omran, \& Cobanoglu, 2017). In the mobile device environment, perceived usefulness is described in terms of how efficiently mobile services can be incorporated into daily operations. In general, consumers tend to have a positive intention to adopt the benefits provided by mobile apps.

In this study, TAM is used to assess interactions between constructs and also to assess the relationship between the factors associated with perceived usefulness and perceived ease of use. In addition, perceived ease of use and perceived usefulness are used as moderator variables to assess the impact between the external factors affecting customers' attitudes and intentions to use mobile apps.

\subsection{E-Servicescape standards for tourism apps}

The e-servicescape environment studies have emerged that have shown consumer perceptions, emotions, and trends (Huang et al., 2017). According to State Koering's view, the internet environment evolves positively evolves from the traditional servicescape. It was designed to create a better impression and to more effectively help customers have a positive customer service experience (Teng, Ni, \& Chen, 2018). 
Wu et al. (2017) identified that the e-servicescape environment was inclusive environmental cues that indirectly affected clients. The cues refer to evidence related to customer perceptions, satisfaction, purchase intent, and trust (Harris \& Goode, 2010). Many studies mentioned the relationship between the e-servicescape environment and consumer behavior. The e-servicescape environment within the service offered by the provider is comprised of the surrounding conditions, functions, and space. Further studies found that color and light (as parts of the e-servicescape environment) affect customer attitudes towards using that service (Teng, Ni, \& Chen, 2018). This also happens in almost exactly the same way in the tourism mobile app environment.

Hypothesis 1: The e-servicescape environment will have positively effect on attitudes towards using tourism app.

\subsection{Electronic-Word-of-Mouth (eWOM) communication}

Electronic word-of-mouth (eWOM) communication is one of the important marketing strategies in the areas of social media. Consumers have the habit of sharing information with others on social networks such as Facebook or Twitter. eWOM is considered to be one of the traditional marketing methods that bring great business results. Customer reviews of products and services are numerous, and they affect attitudes towards potential customers (Cantallops \& Salvi, 2014). Consequently, companies encourage their customers to write reviews of products and online services including those where the use of easy- to- use apps is a criterion (Stoyanov et al., 2015).

The change in attitude through the influence of eWOM communication is based on the trust of individuals towards its origin. According to Maio, Haddock, and Verplanken (2018), there are two dimensions of attitudes: effective and cognitive. An effective attitude is an extent to which a person loves an object and the attitudes of perception are the individual's belief in something.

Hypothesis 2: eWOM communication will have positively effect on attitudes towards using tourism app use.

\subsection{Attitudes towards using tourism apps}

Smith et al. (2015) suggest that consumers with a positive opinion about their beliefs and intentions will develop trust in their beliefs. Attitudes are an important turning point in understanding the adoption of new technology with TAM theory. Customer attitudes towards the use of new technology are also examined by three attitudinal factors: perceived ease of use (PEOU), perceived usefulness (PU), and individual intentions to use technology. Kim et al. (2009) suggested that users' attitudes toward mobile devices are that such devices are good and entertaining and that such attitudes, therefore, affect user intentions. Block, Glavas, Mannor, and Erskine (2017) have suggested that attitudes are important when engaging in activities

According to TAM theory, the main factor that affects the intention to use apps is the individual's attitude towards technology (Hong, Lin, \& Hsieh, 2017). Attitudes play an important role in the decision-making process (Manning \& DiLollo, 2017). Studies have shown that a relationship between attitudes and intentions is formed in the mind, and is used to 
guess intentions (Yang \& Yoo, 2004). A study of mobile app adoption in business suggests that attitudes have a positive effect on consumer intentions to continue using the service. The results show that attitudes are a strong predictor of the intention to continue using an app (Shaikh \& Karjaluoto, 2015).

Hypothesis 3: Attitudes towards using tourism apps will have positively effect on tourism app adoption intentions.

Hypothesis 4: Perceived ease of use will have (positively) effect on attitudes towards tourism app use.

Hypothesis 5: Perceived usefulness will have (positively) effect on attitudes towards tourism app use.

\subsection{Intentions to adopt tourism apps}

Mobile users accept the use of apps when they perform their first mobile activities. More specifically, consumers accept apps when they are downloaded. The increase in the number of people who use phone apps means that the number of people who accept apps is higher than those who do not. Many studies have addressed the adoption of technology with theories and models such as the technology acceptance model (TAM), the theory of reasoned action (TRA), the unified theory of acceptance and use of technology (UTAUT), and the theory of planned behavior (TBA). With TAM, it is determined that when a person decides to use technology, their decision is strongly affected by perceived usefulness and perceived ease of use. In the field of tourism, information technology apps are successful and highly effective in influencing consumers and their intentions to visit destinations through tourism apps.

Hypothesis 6: Intentions to adopt tourism apps will positively affect to intentions to visit tourism destinations.

\subsection{Intentions to visit tourism destinations}

In addition, there is a correlation between behavior and intention to visit the destination (Prayag, Hosany, Muskat, \& Del Chiappa, 2017). Tourism destinations with negative images will be excluded from the decision-making process of tourists; and positive image destinations will be selected (Tan \& Wu, 2016).

Information technology apps such as augmented reality (AR) apps are an important factor in the field of tourism. Studies have examined the relationship between information technology and tourism because of the use of influence by travel experience and behavioral factors (Kim \& Yang, 2017). At tourism destinations, when using AR, tourists will express positive or negative attitudes towards AR. Destination images are important elements in the creation of the intentions of potential visitors to revisit that destination (Papadimitriou, Kaplanidou, \& Apostolopoulou, 2018). In addition, according to H. Kurgun, O. A. Kurgun, and Aktaş (2018) the promised use of internet technology apps (such as AR apps) at a destination advertised on the website is an important motivation for travel to that destination

Hypothesis 7: e-Servicescape environments for tourism apps will positively affect intentions to visit tourism destinations. 
Pizam and Tasci (2018) explain that providing the aesthetics of the e-servicescape environment is very important and that traditional services must be adapted to the surrounding environment and space/function of the virtual landscape. In addition, other studies also mention the positive aspects of the e-servicescape environment in the web system such as hospitals and tourism destinations to the intentions of customers. The use of the website is to display information and brand image and to increase the positive of the brand and increase the intentions to use the service.

Previous studies included the intentions to purchase services and products (Wang, 2018), to seek (Braunstein-Bercovitz \& Lipshits-Braziler, 2017), to use, to travel (Kaplan, Wrzesinska, \& Prato, 2018), to participate in festivals (Ye, Zhang, \& Yuan, 2017), and to follow the advice of the online travel community (Casalo, Flavián, \& Ibanez-Sanchez, 2017).

Hypothesis 8: eWOM communication for tourism apps will positively affect intentions to visit tourism destinations.

\subsection{The Moderating effect of perceived ease of use on the relationship of e-servicescape communications for tourism apps and attitudes towards using tourism apps}

According Hakim and Deswindi (2015) argued that the e-servicescape environment is designed to impress the online environment when a customer experiences service. The e-servicescape environment is also defined as an atmospheric environment in virtual space when establishing a relationship between customers and suppliers (Wu et al., 2017). Hopkins, Grove, Raymond, and LaForge (2009) stated that attitudes towards using application with respect to what it offers was directly and/or indirectly affected by the design of the e-servicescape environment. Karjaluoto, Shaikh, Saarijärvi, and Saraniemi (2018) have determined that the perceived ease of use of online apps contributes to the impression of the customer and thus affects attitudes positively effects attitudes when customers are using mobile apps. Lindberg, Salomonson, Sundström, and Wendin (2018) showed that the e-servicescape environment on apps ought to be designed to ensure the aesthetics, layout, and functions suitable for consumers. The e-servicescape environment design ensures that an app is easy to use and this implies that the users' attitudes are already positive. Alternatively, it has a positive impact on users' attitudes regarding, and intent to use, the apps.

Hypothesis 9: Perceived ease-of-use characteristics moderate the influence of the e-servicescape environment of tourism apps and attitudes towards using tourism apps.

\subsection{The moderating effect of perceived usefulness in the relationship between e-servicescapes of tourism apps and attitudes towards using tourism apps}

According to Huang, Mou, and Liu (2017a), the e-servicescape affects consumers' attitudes towards using apps and to meet their needs. Hopkins et al. (2009) stated that all the dimensions of the e-servicescape environment affected customers' attitudes towards using technology, yet ambient conditions had a huge impact. This virtual environment helps customers observe and experience potential products or services before consuming them. Davis, Bagozzi, and Warshaw (1989) showed that "perceived usefulness" is considered as being the degree 
of confidence that the use of mobile apps will enhance individuals' performance, and they showed that it impacts on attitudes through the use of apps.

Consequently, perceived usefulness is considered (o be a very important factor in providing a value between the e-servicescape environment and consumers' attitudes. Mobile apps are increasingly becoming popular and have been identified as being perceived as useful. It serves as a determining factor for influencing consumers' attitudes towards the use of innovations; and it serves to provide customers with more efficient and convenient apps while using services (Chen \& Sundar, 2018, April). The design of the e-servicescape environment ensures the perceived usefulness the apps and that perceived usefulness has a positive impact on users' attitudes and intent to use the apps.

Hypothesis 10: The perceived usefulness of characteristics moderates the influence of the e-servicescape environment for tourism apps and attitudes towards using tourism apps.

\subsection{The moderating effect of perceived usefulness in the relationship between eWOM communication for tourism apps and attitudes towards using tourism apps}

eWOM communication is an important and useful source of information for travelers seeking destination information and choosing suitable destinations online (Pesonen \& Pasanen, 2017). eWOM communication has a positive impact on shaping attitudes by using mobile apps when deciding which tourism destination to choose. Mobile apps will be a useful tool for travelers to make the right decision. Perceived usefulness is an important factor and determines the attitudes of travelers and the intentions to use an app for tourism purposes (Choi, Wang, \& Sparks, 2018).

User trust in the advice given through eWOM communication has a significant influence on people's attitudes towards using apps (Chu, Lien, \& Cao, 2018). Ayeh, Au, and

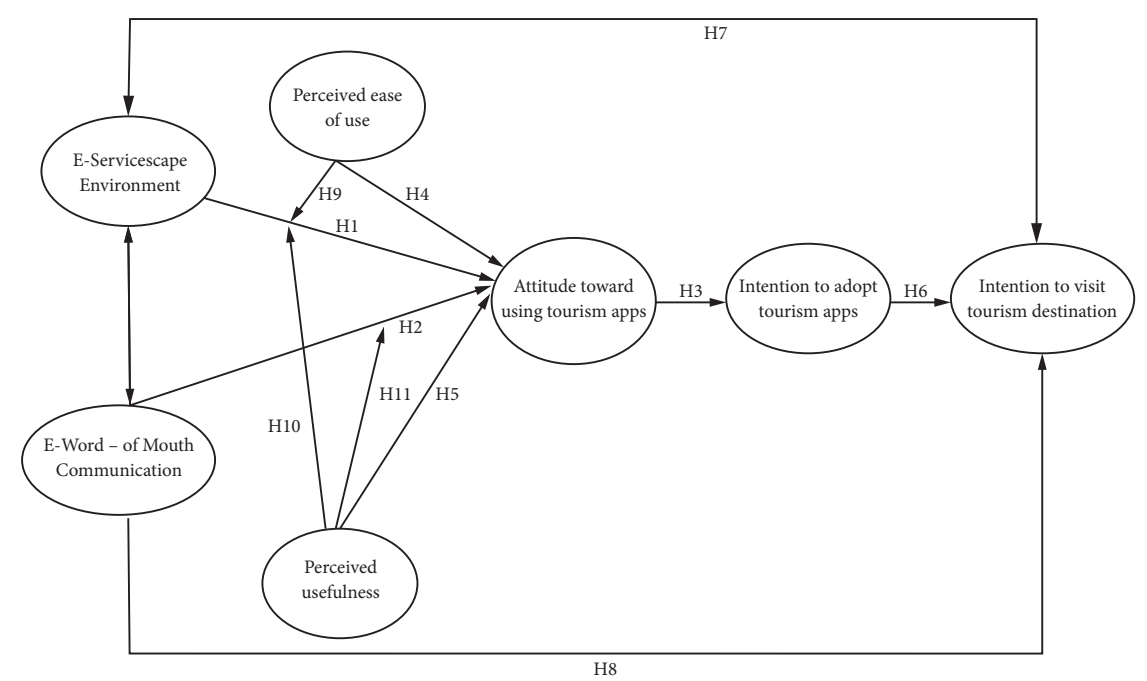

Figure 1. Research model 
Law (2013) also suggested that there is a positive impact of attitudes to eWOM communication, which has a positive impact on future travel plans. At the same time, the perception of usefulness has a major impact through eWOM communication and attitudes through using such apps.

Hypothesis 11: Perceived usefulness characteristics moderate the influence of eWOM communication for tourism apps and attitudes towards using tourism apps.

\section{Research procedure}

\subsection{Research space}

Our survey was conducted from the middle of November 2018 to the middle of December 2018 in Ho Chi Minh City (HCMC), Vietnam. HCMC conveniently borders with many provinces in the Southwestern and Southeastern regions, creating favorable conditions for the development of economic and tourism sectors. In order to perform this research, this study has chosen three of the most attractive tourism destinations of HCMC: (1) Notre-dame Cathedral Basilica of Saigon, (2) Ben Thanh market, (3) Reunification Palace. They are famous structures with the great value of art and history. These three destinations have been chosen for this research because they attract a large number of foreign tourists. The three tourism operators have been contacted for permissions for this research.

\subsection{Data collection}

The questionnaire assessed respondent levels of agreement or disagreement with all the constructs (with a statement for the measurement in the study and the questionnaires) using a five-point Likert scale ranging from " $1=$ strongly disagree" to " $5=$ strongly agree" (Casaló et al., 2011). All respondents completed a questionnaire after they had read an explanation about how to share information. The questionnaire consisted of eight parts.

Twenty students at Ho Chi Minh City University of Culture voluntarily helped the authors to deliver the printed questionnaires to appropriate participants and then collect their responses. These students were divided into three groups. Six of them went to the Notredame Cathedral, eight to Ben Thanh market, and the other six to the Reunification Palace. They also had been trained before they performed the research for appropriate methods. After filling the survey, every tourist would be offered a small notebook of appreciation for their participation.

650 questionnaires were sent to tourists who had known about tourism mobile apps or had been using them for seeking information on the smartphone. Eventually, 630 questionnaires were successfully collected for analysis. A response rate of $96.9 \%$ was obtained. In order to achieve the purposes of this research and test the hypotheses, SPSS 23.0 and partial least squares (SmartPLS) software analysis and choose using SmartPLS 3.0 software will be employed to analyze the collected data. 


\section{Findings}

\subsection{Profiles of the respondents}

Concerning the respondent's profile in Table 1, the frequency analysis indicated that 364 (58\%) of the respondents were male, and 266 (42\%) were female. The age groups were as follows: $168(26.6 \%)$ of the respondents were aged 20-29, followed by 30-39 (163, $25.9 \%)$, $40-49(138,21,9 \%)$, and $>50(161,25.6 \%)$. The monthly income of respondents was USD $<300$ (103, 16.3\%), 301-600 USD (169, 26.8\%), 601-900 USD (113, 17.9\%), 901-1200 USD $(214,34 \%)$ and $>1200$ USD (31, 5\%). Most respondents were from Vietnam (48\%), followed by Singapore $14.6 \%)$, Thailand (12\%), China (10.4\%), Indonesia (10\%) and Taiwan $(5.0 \%)$.

Table 1. Demographic information for the sample

\begin{tabular}{|l|c|c|c|}
\hline \multicolumn{3}{|c|}{ Characteristics Frequency \% } \\
\hline Gender & Male & 364 & 58 \\
& Female & 266 & 42 \\
\hline Age & $20-29$ & 168 & 26.6 \\
& $30-39$ & 163 & 25,9 \\
& $40-49$ & 138 & 21,9 \\
Income (USD/ & $>50$ & 161 & 25.6 \\
month) & $<300$ & 103 & 16.3 \\
& $301-600$ & 169 & 26.8 \\
& $601-900$ & 113 & 17.9 \\
& $901-1200$ & 214 & 34 \\
Nationality & $>1200$ & 31 & 5 \\
& Vietnam & 302 & 48 \\
& Indonesia & 92 & 10 \\
& Singapore & 76 & 14.6 \\
& Thailand & 66 & 12 \\
Total & China & 31 & 5 \\
\hline
\end{tabular}

\subsection{Reliability and validity}

The reliability and validity of the measurement model in Figure 1 was estimated. The main variables were eWOM communication and the e-servicescape environment. In addition, two moderators' variables are perceived ease of use and perceived usefulness; these were also analyzed to clarify the impact on the primary variables. A summary of the factor analysis structure is presented in Table 2. Reliability analysis is a method for checking the consistency of measurement variables The items to achieve internal consistency must be worth more than 0.7 with 0.5 being the lowest acceptable value (Sekaran \& Bougie, 2010). According to Sekaran and Bougie (2016), the closer the Cronbach's alpha is to the value 1, the higher the internal consistency is. Table 2 shows all Cronbach's alpha values for the study variables are greater than 0.70. All results showed in Table 2: 
Table 2. Construct of factor analysis and reliability analysis

\begin{tabular}{|l|c|c|c|}
\hline \multicolumn{1}{|c|}{ Construct } & $\begin{array}{c}\text { No. of } \\
\text { Items }\end{array}$ & Factor Loading & $\begin{array}{c}\text { Cronbach's } \\
\text { Alpha }\end{array}$ \\
\hline e-Servicescape environment for tourism apps & 11 & $.910-.967$ & .988 \\
\hline e-Word-of-Mouth Communication for Tourism Apps & 7 & $.950-.986$ & .989 \\
\hline Perceived Usefulness & 4 & $.936-.975$ & .972 \\
\hline Perceived Ease of Use & 4 & $.967-.985$ & .982 \\
\hline Attitude towards Using Tourism Apps & 4 & $.975-.991$ & .990 \\
\hline Intention to adopt Tourism Apps & 3 & $.968-.983$ & .976 \\
\hline Intention to Visit Tourism Destinations & 3 & $.964-.969$ & .959 \\
\hline
\end{tabular}

\subsection{Evaluation of the measurement model}

According to Hair, Hult, Ringle, and Sarstedt (2011), there are several criteria in the evaluation study for measuring the reliability and validity of the measurement model. The first criterion is the determinant $\mathrm{R} 2$, which is used to measure the level of interpretation of each latent variable.

Using the above criteria, the validated reliability of the measurement model is clearly verified. The results showed the coefficient of determination R2 for 7 endogenous latent variables being as follows: 0.9 for the "attitude towards using tourism apps" factor and "intentions to visit destinations" factor; 0.8 for the "intention to adopt tourism apps" factor; and 0.9 for the "intention to adopt tourism apps" factor. According to Schroer and Herterl (2009), the coefficients for determining R2 are considered as being significant. The AVE structure is much higher than the 0.5 indicator as suggested and this proves the relevance and rationality of the research. The Cronbach's alpha coefficients satisfy the predefined requirement of 0.7 and confirm the internal consistency of the items. The CR coefficients are sorted higher than 0.8 and show the difference between relatively strong indicators. With the above conclusions, it can be concluded that the reliability and validity of the research model are appropriate and allows for the evaluation of the structural model.

Table 3. Evaluation of structural model and hypothesis testing

\begin{tabular}{|c|l|c|c|c|c|}
\hline Hypo. & \multicolumn{1}{|c|}{ Path } & $\begin{array}{c}\text { Standardize } \\
\text { Estimate }\end{array}$ & t-Value & p-Value & Results \\
\hline H1 & $\begin{array}{l}\text { e-Servicescapes for app } \rightarrow \text { Attitude towards } \\
\text { tourism app use }\end{array}$ & 0.0 & 1.1 & - & $\begin{array}{c}\text { Not } \\
\text { Supported }\end{array}$ \\
\hline H2 & $\begin{array}{l}\text { eWOM communication for an app } \rightarrow \text { Attitude } \\
\text { towards using tourism apps }\end{array}$ & 0.3 & 6.4 & $* * *$ & Supported \\
\hline H3 & $\begin{array}{l}\text { Attitude towards using an app } \rightarrow \text { Intention to } \\
\text { adopt tourism apps }\end{array}$ & 0.9 & 71.7 & $* * *$ & Supported \\
\hline H4 & $\begin{array}{l}\text { Perceived ease of use } \rightarrow \text { Attitude towards } \\
\text { tourism app use Intention to adopt tourism } \\
\text { apps } \rightarrow \text { Intention to visit destination }\end{array}$ & 0.3 & 9.0 & $* * *$ & Supported \\
\hline
\end{tabular}


Continue of Table 1

\begin{tabular}{|c|l|c|c|c|l|}
\hline Hypo. & \multicolumn{1}{|c|}{ Path } & $\begin{array}{c}\text { Standardize } \\
\text { Estimate }\end{array}$ & t-Value & p-Value & Results \\
\hline H5 & $\begin{array}{l}\text { Perceived usefulness } \rightarrow \text { Attitude towards } \\
\text { tourism app use }\end{array}$ & 0.4 & 26.3 & $* * *$ & Supported \\
\hline H6 & $\begin{array}{l}\text { Intention to adopt tourism apps } \rightarrow \text { Intention } \\
\text { to visit destinations }\end{array}$ & 0.7 & 15.5 & $* * *$ & Supported \\
\hline H7 & $\begin{array}{l}\text { e-Servicescape environments for tourism apps } \\
\rightarrow \text { Intention to visit destinations }\end{array}$ & 0.1 & 2.2 & $* * *$ & Supported \\
\hline H8 & $\begin{array}{l}\text { eWOM for tourism apps } \rightarrow \text { Intention to visit } \\
\text { destinations }\end{array}$ & 0.2 & 6.3 & $* * *$ & Supported \\
\hline H9 & $\begin{array}{l}\text { Perceived Ease of Use moderates the } \\
\text { e-servicescape environment for tourism apps } \\
\rightarrow \text { Attitude towards tourism app use }\end{array}$ & 0.1 & 2.4 & $* * *$ & Supported \\
\hline H10 & $\begin{array}{l}\text { Perceived usefulness moderates the } \\
\text { e-servicescape environment for tourism apps } \\
\rightarrow \text { Attitude towards tourism app use }\end{array}$ & -0.1 & 1.9 & - & $\begin{array}{l}\text { Not } \\
\text { Supported }\end{array}$ \\
\hline H11 & $\begin{array}{l}\text { Perceived usefulness moderates eWOM } \\
\text { communication for tourism apps } \rightarrow \text { Attitude } \\
\text { towards tourism app use }\end{array}$ & 0.1 & 2.8 & $* * *$ & Supported \\
\hline
\end{tabular}

${ }^{* * *} p<0.001,{ }^{* *} p<0.01,{ }^{*} p<0.05$.

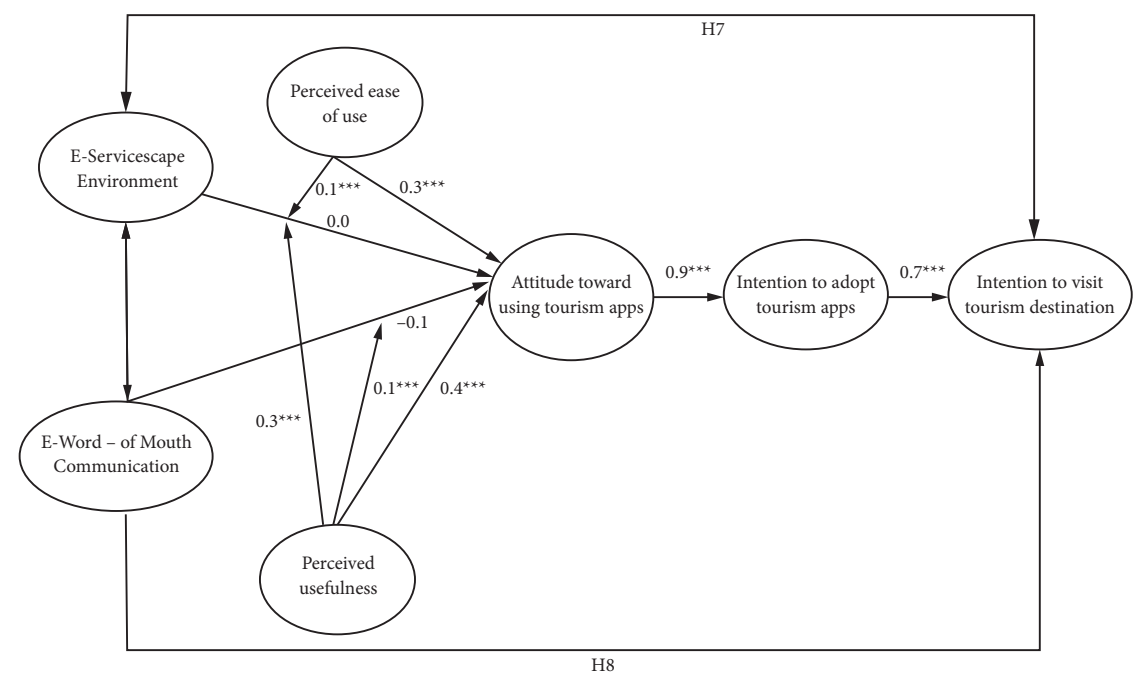

Figure 2. The measurement model of this research

\section{Discussion}

Structural models with research hypotheses were tested using partial least squares (PLSs) analysis and choose using SmartPLS 3.0 software and bootstrapping technique (Table 3). Using a sample of 630, a non-parametric bootstrapping procedure was used; with 5,000 additional samples being used to obtain meaningful statistics for hypothesis testing. The 
goodness-of-fit (GOF) index is used to measure all the matches overall between the data and research models. The GoF of this research model is 0.91 ; it is considered as being large. The results confirm that the research model structure is consistent with high predictive power. Figure 2 shows the direct path for the structural model.

Hypothesis 1 was tested by examining the path coefficient between the e-servicescape environment for tourism apps and attitudes towards using tourism apps ( $\beta=0.0$, t-value $=$ 1.1). The results showed that the e-servicescape environment for tourism apps did not necessarily have a positive attitude towards tourism app use. The meaning that even a quality e-servicescape environment did not necessarily result in a positive attitude towards the apps. For instance, maybe the app was loaded with so many quality features that it took extra time to load, thus resulting in both positive and negative attitudes.

Hypothesis 2 was tested by examining the path coefficient between e-WOM for apps and attitude towards tourism app use $(\beta=0.3, \mathrm{t}$-value $=6.4)$. The results showed that eWOM communications for apps were likely to result in positive attitudes towards using tourism apps. Therefore, the findings of this study show that eWOM communication affects choosing tourism destination while using mobile apps and the impact of these two relationships are particularly positive. Besides, the impact of eWOM communication and the e-servicescape environment on users' choices has existed.

Hypothesis 3 was tested by examining the path coefficient between attitudes towards tourism app use and the intention to adopt tourism apps $(\beta=0.9$, t-value $=71.7)$. The results showed that attitudes towards using tourism apps were likely to result in positive intentions to adopt tourism apps. Hypothesis 4 was tested by examining the path coefficient between perceived ease of use and attitude towards using tourism apps $(\beta=0.7$, $t$-value $=15.5)$. The results showed that perceived ease of use will positively affect attitudes towards tourism app use. A study by Gefen, Karahanna, and Straub (2003) suggested that the perceived ease of use has a positive effect on the continued use of some other form of technology in the current technological context.

Hypothesis 5 was tested by examining the path coefficient between perceived usefulness and attitude towards using tourism apps $(\beta=0.1$, t-value $=2.2)$. The results showed that perceived usefulness will positively affect attitudes towards tourism app use. Hypothesis 6 was tested by examining the path coefficient between the intention to adopt tourism apps and the intention to visit tourism destinations $(\beta=0.2$, t-value $=6.3)$. The results showed that intentions to adopt tourism apps will positively affect intentions to visit tourism destinations. Hypothesis 7 was tested by examining the path coefficient between the e-servicescape environment for tourism apps and intentions to visit tourism destinations $(\beta=0.3$, t-value $=$ 9.0). The results showed that the e-servicescape environment for tourism apps will positively affect intentions to visit tourism destinations. Hypothesis 8 was tested by examining the path coefficient between eWOM communication for tourism apps and intentions to visit tourism destinations $(\beta=0.4$, t-value $=6.3)$. The results showed that eWOM communication for tourism apps will positively affect intentions to visit tourism destinations. Hypothesis 9 was tested by examining the path coefficient between perceived ease of use characteristics which moderate the effect of tourism apps on the e-servicescape environments for tourism apps and the attitude towards using tourism apps $(\beta=0.1$, t-value $=2.4)$. The results showed that 
perceived ease of use characteristics are moderate and will positively affect/influence both the e-servicescape environments for tourism apps and attitudes towards tourism app use. Hypothesis 10 was tested by examining the path coefficient between the moderating effect of perceived usefulness on the relationship of the e-servicescape environments for tourism apps and attitude towards tourism app use $(\beta=-0.1$, t-value $=1.9)$. The results showed that perceived usefulness characteristics moderate but will not positively affect/influence both the relationship with the e-servicescape environments for tourism apps and attitudes towards using tourism apps.

Hypothesis 11 was tested by examining the path coefficient between the moderating effect of perceived usefulness on the relationship of eWOM communication for tourism apps and attitude towards tourism apps $(\beta=0.1$, t-value $=2.8)$. Hypothesis 11 's result showed that perceived usefulness characteristics moderate and will positively affect/influence both eWOM communication for tourism apps and attitudes towards tourism app use.

\section{Conclusions}

The study examines how consumers adopt mobile tourism apps and use tourism apps to orient customer intentions to visit tourism destinations. It also uses key factors such as perceived usefulness, perceived ease of use and attitudes towards using apps to clarify the extent to which the user is affected by apps. This study found that there are many factors that determine the impact of mobile users on tourism - factors such as perceived usefulness, perceived ease of use, e-servicescape environment, and eWOM communication. This result is consistent with previous studies using TAM models (Hsu et al., 2011). Consumers accept mobile apps because they are more likely to accept apps if they are perceived as useful and easy to use. In this study, perceived usefulness and perceived ease of use had a positive effect on attitudes towards using tourism apps - and this is also the study's contribution. It reaffirms the positive relationship and impact between perceived usefulness and perceived ease of use. The study also evaluates the relationship between eWOM communication and the e-servicescape environment in their tourism products (such as apps) or tourism services, affecting attitudes towards using tourism apps. These are the two main factors that directly affect consumer attitudes towards using tourism apps, with the peculiarity that mobile apps were made for smartphones. In addition to the necessary factors such as perceived usefulness and perceived ease of use, external factors - such as eWOM communication and the e-servicescape environment - also create attitudes that affect the use of apps for travel purposes. This is one of the factors that greatly affect the attitudes of consumers. The study also demonstrates that the impact of eWOM communication on tourism apps is strongly affected by attitudes towards using mobile tourism apps. Factors such as experience in the use of mobile apps, working in combination with elements of eWOM communication, are an issue that app providers and marketers should pay attention to in order to better understand the customer. In this study, however, the effect of the e-servicescape environment for tourism apps on the attitudes towards using tourism apps was not significant even at a low level of impact. Previous studies have shown that this is also an important factor in influencing attitudes towards using tourism products (such as 
apps) or tourism services (Hanafizadeh, Behboudi, Koshksaray, \& Tabar, 2014). The main thing that can be concluded is that consumers still tend to choose mobile apps, even if those the e-servicescape environments of those apps are unattractive.

The research has discovered how eWOM communication, the e-servicescape environment affect attitude while using tourism apps, intention to adopt and intention to visit tourism destination in the relationship with perceived usefulness and perceived ease of use.

Theoretically, this study attempted an empirical explanation of intent to visit destinations with a TAM model using moderating factors such as not only perceived usefulness itself, but also perceived usefulness in the relationship with eWOM communication, the e-servicescape environment, and attitudes towards using tourism apps. Most significantly, the initial assumptions of this study support the important factors (eWOM communication, the e-servicescape environment) affecting attitudes towards using tourism apps. Huang et al. (2017) argue that the use of information technology makes the experience of travelers better. Factors like eWOM communication and e-servicescape are two important factors that are thought to have a great impact on customer behavior. This study considers the two factors in providing mobile apps in the field of tourism for clients. The research evaluates the impact of two factors - perceived ease of use and perceived usefulness - with regards to attitudes towards apps in the field of tourism. The impact of these factors on travelers intending to visit destinations is very important. Research indicates that perceived ease of use and perceived usefulness have a positive effect on behavioral patterns through the use of tourist apps. Besides, we also evaluate two factors - eWOM communication and the e-servicescape environment for tourism apps - that have a positive impact on intentions to visit tourism destinations. This research has shown that travelers are easily affected by mobile apps with eWOM communication elements and travelers highly rate apps which include such elements. Therefore, eWOM communication and the e-servicescape environment are two important factors that affect the attitudes and intentions to visit tourist destinations. These two factors have been clearly examined by TAM and are completely consistent with the original research model.

Practically, the study points out that eWOM communication and e-servicescape environmental factors are very important in influencing customer attitudes. Therefore, app providers need to have new effective marketing strategies such as controlling customer psychology or increasing positive feedback from users of the apps. Moreover, the customers will be influenced by factors such as eWOM communication, the e-servicescape environment, the perceived ease of use, and the perceived usefulness of mobile apps. Therefore, app providers need to understand the positive and negative effects of these factors in order to build and create the right apps. For these travel company, in building systems for customers, travel agencies should be aware that the customers may see the active app, the two factors of perceived ease of use and perceived usefulness both directly and indirectly affect the attitudes of app users. Moreover, some implications provide application designers with basic ideas for more effective applications designing in the future. The contribution of this study shows that an application needs to be built with an online feedback mechanism as strong support for more effective updates. Therefore, besides the implication of word-of-mouth, an application should display information attractively, and also display comparing information to help mobile users to make a decision easily. 
The primary limitation of this study is that the developed scale should be checked against more diverse samples using tourism apps from different countries and regions. Future researchers need to check the scale in wider and comparatively more diverse contexts to identify the impacts of perception and behaviours regarding tourism apps' consumption value on customers who use the apps. The study examined the role of perceived ease of use and the perception of perceived usefulness as background in moderating the relationships between attitudes, using tourism apps constructs and the identified constructs.

Future research needs to determine how perceived ease of use and perceived usefulness affect the relationship between tourism apps and intention to adopt apps and other constructs. The study focused on how customers adopt mobile apps in destination selection but did so without considering the factors involved in their use of mobile apps and their motivations for travel. Future studies need to find out more about the satisfaction of mobile apps users both before and after usage and the experience-sharing factor in other fields such as food and beverage, sport, technology, and business. Finally, future research should do so by testing a variety of apps and expanding the demographics model in theory and practice to see whether targeting this demographic would result in an increase in higher-priced sales.

\section{References}

Ayeh, J. K., Au, N., \& Law, R. (2013). “Do we believe in TripAdvisor?” Examining credibility perceptions and online travelers' attitude toward using user-generated content. Journal of Travel Research, 52(4), 437-452. https://doi.org/10.1177/0047287512475217

Berman, B. (2016). Referral marketing: harnessing the power of your customers. Business Horizons, 59(1), 19-28. https://doi.org/10.1016/j.bushor.2015.08.001

Block, E. S., Glavas, A., Mannor, M. J., \& Erskine, L. (2017). Business for good? An investigation into the strategies firms use to maximize the impact of financial corporate philanthropy on employee attitudes. Journal of Business Ethics, 146(1), 167-183. https://doi.org/10.1007/s10551-015-2930-8

Braunstein-Bercovitz, H., \& Lipshits-Braziler, Y. (2017). Career-planning beliefs as predictors of intentions to seek career counseling. Journal of career assessment, 25(2), 352-368. https://doi.org/10.1177/1069072715616129

Cantallops, A. S., \& Salvi, F. (2014). New consumer behavior: A review of research on eWOM and hotels. International Journal of Hospitality Management, 36, 41-51. https://doi.org/10.1016/j.ijhm.2013.08.007

Casaló, L.V., Flavián, C. and Guinalíu, M., 2011. Understanding the intention to follow the advice obtained in an online travel community. Computers in Human Behavior, 27(2), 622-633. https://doi.org/10.1016/j.chb.2010.04.013

Casalo, L. V., Flavián, C., \& Ibanez-Sanchez, S. (2017). Antecedents of consumer intention to follow and recommend an Instagram account. Online Information Review, 41(7), 1046-1063. https://doi.org/10.1108/OIR-09-2016-0253

Chin, W. W., Marcolin, B. L., \& Newsted, P. R. (2003). A partial least squares latent variable modeling approach for measuring interaction effects: Results from a Monte Carlo simulation study and an electronic-mail emotion/adoption study. Information Systems Research, 14(2), 189-217. https://doi.org/10.1287/isre.14.2.189.16018

Chiu, C. M., \& Wang, E. T. (2008). Understanding web-based learning continuance intention: the role of subjective task value. Information \& Management, 45(3), 194-201.

https://doi.org/10.1016/j.im.2008.02.003 
Chen, T. W., \& Sundar, S. S. (2018, April). This app would like to use your current location to better serve you: importance of user assent and system transparency in personalized mobile services. In Proceedings of the 2018 CHI Conference on Human Factors in Computing Systems (p. 537). https://doi.org/10.1145/3173574.3174111

Chu, S. C., Lien, C. H., \& Cao, Y. (2018). Electronic word-of-mouth (eWOM) on WeChat: examining the influence of sense of belonging, need for self-enhancement, and consumer engagement on Chinese travellers' eWOM. International Journal of Advertising, 1-24. https://doi.org/10.1080/02650487.2018.1470917

Choi, K., Wang, Y., \& Sparks, B. (2018). Travel app users' continued use intentions: it's a matter of value and trust. Journal of Travel \& Tourism Marketing, 1-13. https://doi.org/10.1080/10548408.2018.1505580

Davis, F. D. (1985). A technology acceptance model for empirically testing new end-user information systems: theory and results (Doctoral dissertation). Massachusetts Institute of Technology.

Davis, F. D., Bagozzi, R. P., \& Warshaw, P. R. (1989). User acceptance of computer technology: a comparison of two theoretical models. Management Science, 35(8), 982-1003. https://doi.org/10.1287/mnsc.35.8.982

Di Pietro, L., Di Virgilio, F., \& Pantano, E. (2012). Social network for the choice of tourist destination: Attitude and behavioural intention. Journal of Hospitality and Tourism Technology, 3(1), 60-76. https://doi.org/10.1108/17579881211206543

eMarketer. (2014, May 2). U.S. mobile users turn to smartphones, tablets to redeem coupons. Retrieved from http://www.emarketer.com/Article/US-Mobile-UsersTurn-Smartphones-Tablets-RedeemCoupons/1010801

eMarketer. (2016). Most digital buyers will make purchases via a smartphone by 2017. Retrieved from http://www.emarketer.com/Article/Most-Digital-Buyers-Will-Make-Purchases-via-Smartphoneby-2017/1013590

Gefen, D., Karahanna, E., \& Straub, D. W. (2003). Trust and TAM in online shopping: An integrated model. MIS Quarterly, 27(1), 51-90. https://doi.org/10.2307/30036519

Goyette, I., Ricard, L., Bergeron, J., \& Marticotte, F. (2010). e-WOM Scale: word-of-mouth measurement scale for e-services context. Canadian Journal of Administrative Sciences/Revue Canadienne des Sciences de l'Administration, 27(1), 5-23. https://doi.org/10.1002/cjas.129

Hair Jr, J. F., Hult, G. T. M., Ringle, C., \& Sarstedt, M. (2016). A primer on partial least squares structural equation modeling (PLS-SEM). Sage Publications.

Hakim, L., \& Deswindi, L. (2015). Assessing the effects of e-servicescape on customer intention: A study on the hospital websites in South Jakarta. Procedia-Social and Behavioral Sciences, 169, 227-239. https://doi.org/10.1016/j.sbspro.2015.01.306

Hanafizadeh, P., Behboudi, M., Koshksaray, A. A., \& Tabar, M. J. S. (2014). Mobile-banking adoption by Iranian bank clients. Telematics and Informatics, 31(1), 62-78. https://doi.org/10.1016/j.tele.2012.11.001

Harris, L. C., \& Goode, M. M. (2010). Online servicescapes, trust, and purchase intentions. Journal of Services Marketing, 24(3), 230-243. https://doi.org/10.1108/08876041011040631

Henseler, J., Ringle, C. M., \& Sinkovics, R. R. (2009). The use of partial least squares path modeling in international marketing. In New challenges to international marketing (pp. 277-319). Emerald Group Publishing Limited. https://doi.org/10.1007/978-3-319-53469-5_12

Hong, J. C., Lin, P. H., \& Hsieh, P. C. (2017). The effect of consumer innovativeness on perceived value and continuance intention to use smartwatch. Computers in Human Behavior, 67, 264-272. https://doi.org/10.1016/j.chb.2016.11.001

Hopkins, C. D., Grove, S. J., Raymond, M. A., \& LaForge, M. C. (2009). Designing the e-servicescape: Implications for online retailers. Journal of Internet Commerce, 8(1-2), 23-43.

https://doi.org/10.1080/15332860903182487 
Huang, D., Li, Z., Mou, J., \& Liu, X. (2017). Effects of flow on young Chinese consumers' purchase intention: a study of e-servicescape in hotel booking context. Information Technology \& Tourism, 17(2), 203-228. https://doi.org/10.1007/s40558-016-0073-0

Hsu, C. L., \& Lin, J. C. C. (2015). What drives purchase intention for paid mobile apps? - An expectation confirmation model with perceived value. Electronic Commerce Research and Applications, 14(1), 46-57. https://doi.org/10.1016/j.elerap.2014.11.003

Hsu, Y. C., \& Ching, Y. H. (2011). Microblogging for strengthening a virtual learning community in an online course. Knowledge Management \& E-Learning: An International Journal, 3(4), 585-598. https://doi.org/ 10.34105/j.kmel.2011.03.039

Kaplan, S., Wrzesinska, D. K., \& Prato, C. G. (2018). The role of existence, relatedness, and growth needs in the intention to use conventional and electric bike sharing in a Driving-Oriented Country (No. 18-02044). Retrieved from https://trid.trb.org/View/1495149

Karjaluoto, H., Shaikh, A. A., Saarijärvi, H., \& Saraniemi, S. (2018). How perceived value drives the use of mobile financial services apps. International Journal of Information Management. https://doi.org/10.1016/j.ijinfomgt.2018.08.014

Kim, W. G., Ng, C. Y. N., \& Kim, Y. S. (2009). Influence of institutional DINESERV on customer satisfaction, return intention, and word-of-mouth. International Journal of Hospitality Management, 28(1), 10-17. https://doi.org/ 10.1016/j.ijhm.2008.03.005

Kim, S. E., Lee, K. Y., Shin, S. I., \& Yang, S. B. (2017). Effects of tourism information quality in social media on destination image formation: The case of Sina Weibo. Information \& Management, 54(6), 687-702. https://doi.org/ 10.1016/j.im.2017.02.009

Kurgun, H., Kurgun, O. A., \& Aktaş, E. (2018). What does Web 4.0 Promise for Tourism Ecosystem? A Qualitative Research on Tourism Ecosystem Stakeholders' Awareness. Journal of Tourism and Hospitality Management, 6(1), 55-65. https://doi.org/10.15640/jthm.v6n1a6

Lindberg, U., Salomonson, N., Sundström, M., \& Wendin, K. (2018). Consumer perception and behavior in the retail foodscape-A study of chilled groceries. Journal of Retailing and Consumer Services, 40, 1-7. https://doi.org/ 10.1016/j.jretconser.2017.09.001

Maio, G. R., Haddock, G., \& Verplanken, B. (2018). The psychology of attitudes and attitude change. Sage Publications Limited. https://doi.org/10.1080/13683500.2015.1043248

Manning, W. H., \& DiLollo, A. (2017). Clinical decision making in fluency disorders. Plural Publishing.

McCarthy, L., Stock, D., \& Verma, R. (2010). How travelers use online and social media channels to make hotel-choice decisions [Electronic article]. Cornell Hospitality Report, 10(18), 6-18.

Papadimitriou, D., Kaplanidou, K., \& Apostolopoulou, A. (2018). Destination image components and word-of-mouth intentions in urban tourism: A multigroup approach. Journal of Hospitality \& Tourism Research, 42(4), 503-527. https://doi.org/10.1177/1096348015584443

Pesonen, J., \& Pasanen, K. (2017). A closer look at tourist information search behaviour when travelling abroad: what is the role of online marketing in choice of destination? In Information and Communication Technologies in Tourism 2017 (pp. 431-443). Springer, Cham. Retrieved from http://link. springer.com/chapter/10.1007/978-3-319-51168-9_31

Pizam, A., \& Tasci, A. D. (2018). Experienscape: expanding the concept of servicescape with a multistakeholder and multi-disciplinary approach (invited paper for "luminaries" special issue of International Journal of Hospitality Management). International Journal of Hospitality Management. https://doi.org/10.1016/j.ijhm.2018.06.010

Prayag, G., Hosany, S., Muskat, B., \& Del Chiappa, G. (2017). Understanding the relationships between tourists' emotional experiences, perceived overall image, satisfaction, and intention to recommend. Journal of Travel Research, 56(1), 41-54. https://doi.org/10.1177/0047287515620567

Schroer, J., \& Hertel, G. (2009). Voluntary engagement in an open web-based encyclopedia: Wikipedians and why they do it. Media Psychology, 12(1), 96-120. https://doi.org/10.1080/15213260802669466 
Sekaran, U., \& Bougie, R. (2016). Research methods for business: A skill building approach. John Wiley \& Sons.

Shankar, V., \& Balasubramanian, S. (2009). Mobile marketing: a synthesis and prognosis. Journal of Interactive Marketing, 23(2), 118-129. https://doi.org/10.1016/j.intmar.2009.02.002

Shaikh, A. A., \& Karjaluoto, H. (2015). Mobile banking adoption: A literature review. Telematics and informatics, 32(1), 129-142. https://doi.org/10.1016/j.tele.2014.05.003

Smith, S. G., Raine, R., Obichere, A., Wolf, M. S., Wardle, J., \& von Wagner, C. (2015). The effect of a supplementary ('gist-based') information leaflet on colorectal cancer knowledge and screening intention: a randomized controlled trial. Journal of Behavioral Medicine, 38(2), 261-272. https://doi.org/10.1007/s10865-014-9596-Z

Stoyanov, S. R., Hides, L., Kavanagh, D. J., Zelenko, O., Tjondronegoro, D., \& Mani, M. (2015). Mobile app rating scale: a new tool for assessing the quality of health mobile apps. JMIR mHealth and uHealth, 3(1). https://doi.org/10.2196/mhealth.3422

Tan, W. K., \& Wu, C. E. (2016). An investigation of the relationships among destination familiarity, destination image and future visit intention. Journal of Destination Marketing \& Management, 5(3), 214-226. https://doi.org/ 10.1016/j.jdmm.2015.12.008

Teng, H. J., Ni, J. J., \& Chen, H. H. (2018). Relationship between e-servicescape and purchase intention among heavy and light internet users. Internet Research, 28(2), 333-350. https://doi.org/10.1108/IntR-10-2016-0303

Ukpabi, D. C., \& Karjaluoto, H. (2017). Consumers' acceptance of information and communications technology in tourism: A review. Telematics and Informatics, 34(5), 618-644. https://doi.org/10.1016/j.tele.2016.12.002

Van Haperen, M. (2012). Validating the e-Servicescape (Doctoral dissertation, Thesis Master). Eindhoven University of Technology, Eindhoven. https://doi.org/10.1016/j.tele.2016.12.002

Venkatesh, V., Davis, F., \& Morris, M. G. (2007). Dead or alive? The development, trajectory and future of technology adoption research. Journal of the Association for Information Systems, 8(4), 1. https://doi.org/10.17705/1jais.00120

Verma, R., Stock, D., \& McCarthy, L. (2012). Customer preferences for online, social media, and mobile innovations in the hospitality industry. Cornell Hospitality Quarterly, 53(3), 183-186. https://doi.org/10.1177/1938965512445161

Wang, H. Y. (2018). Investigating the factors of hospitality company-branded Line stickers that influence users' attitudes toward hospitality companies. International Journal of Contemporary Hospitality Management, 30(3), 1808-1826. https://doi.org/10.1108/IJCHM-09-2016-0551

Wu, W. Y., Quyen, P. T. P., \& Rivas, A. A. A. (2017). How e-servicescapes affect customer online shopping intention: the moderating effects of gender and online purchasing experience. Information Systems and e-Business Management, 15(3), 689-715. https://doi.org/10.1007/s10257-016-0323-x

Yang, H. D., \& Yoo, Y. (2004). It's all about attitude: revisiting the technology acceptance model. Decision Support Systems, 38(1), 19-31. https://doi.org/10.1016/S0167-9236(03)00062-9

Ye, B. H., Zhang, H. Q., \& Yuan, J. (2017). Intentions to participate in wine tourism in an emerging market: Theorization and implications. Journal of Hospitality \& Tourism Research, 41(8), 1007-1031. https://doi.org/10.1177/1096348014525637

Zhang, T., Abound Omran, B., \& Cobanoglu, C. (2017). Generation Y's positive and negative eWOM: use of social media and mobile technology. International Journal of Contemporary Hospitality Management, 29(2), 732-761. https://doi.org/10.1108/IJCHM-10-2015-0611 